\title{
ASPECTOS DO CONTROLE DE CONSTITUCIONALIDADE DE LEIS MUNICIPAIS
}

\author{
ASPECTS OF CONSTITUTIONALITY CONTROL OF MUNICIPAL LAWS
}

Gabriel Dias Marques da Cruz*

\begin{abstract}
Resumo:
Este artigo visa à elucidação dos caracteres do controle de constitucionalidade brasileiro, enfocando, especificamente, a questão das leis municipais. O estudo busca, pois, expor as duas espécies de controle existentes no Brasil, considerando, a princípio, que, no campo do controle incidental, não existem grandes problemas, tendo em vista a larga possibilidade de exame das leis por parte de juízes e tribunais no bojo de nosso sistema. Contudo, na esfera do controle abstrato, é possivel constatar um erro causado pelo legislador constituinte, quando deixou de consagrar a lei municipal como objeto de apreciação pela Suprema Corte, o que traz à baila a idéia de omissão intencional. Baseando-se nesta constatação, o trabalho sugere uma modificação do Sistema brasileiro, com o propósito de criar a permissão para análise direta da lei municipal perante a Constituição, proposta que poderia incrementar a defesa de nossa Carta Magna por parte de uma verdadeira Corte Constitucional.
\end{abstract}

Palavras-chave: Controle de constitucionalidade. Lei municipal. Inconstitucionalidade.

\begin{abstract}
:
This article aims to discover the characteristics of Brazilian's judicial review, focusing, specially, the municipal law. So, the study looks for an exposition of the two species of judicial review that can be found in our country, considering, at first. that there aren't great problems in the concrete field, due to the large possibility of examination through all judges and courts. However, in abstract field, it's possible to find a mistake caused by constitutional legislator, when it didn't make possible submit municipal law under appreciation by Supreme Court, giving us the idea of an intentional omission. Based on this consideration, the paper suggests a modification into brazilian's System, with the purpose of create a permission for a direct analysis between municipal law and Constitution, proposal that could increase its defense by a real Constitutional Court.
\end{abstract}

Keywords: Judicial review. Municipal law. Unconstitutionality.

I. Introdução

O Município representa locus privilegiado da vida do ser humano, sendo nele desenvolvidos os aspectos mais relevantes de sua existência. A Constituição. de 1988, atribuiu ao Município, como se sabe, a condição de peça integrante do nosso

Mestrando em Dircito do Esıado na Faculdade de Direito da Universidade de São Paulo. 
sistema federativo, conferindo-lhe diversas espécies de autonomia, incluindo-se, inclusive, autonomia legislativa.

No que pertence a esta autonomia, empreende-se investigação, neste breve estudo, acerca das especificidades do controle de constitucionalidade da lei municipal. ou seja, verifica-se a congruência desta diante do conteúdo da Carta Magna. Nesse sentido, examinar-se-ão os caracteres operados na via do controle incidental, assim como aqueles relativos ao controle principal, atentando para as falhas e omissões existentes nesta seara.

Ao longo do texto, são feitas sugestões com vistas ao aperfeiçoamento do modelo nacional de controle de constitucionalidade, sem a pretensão, no entanto, de fornecer qualquer tratamento inovador na temática.

2. Breve panorama do controle de constitucionalidade brasileiro

Diante dos elementos estudados, resulta conveniente traçar um breve entendimento acerca do termo controle de constitucionalidade. Vejamos. a princípio, as lições da doutrina acerca da matéria. Neste sentido, Manoel Gonçalves Ferreira Filho acredita que:

Controle de constitucionalidade é, pois, a verificação da adequação de um ato jurídico (particularmente da lei) à Constituição. Envolve a verificação tanto dos requisitos formais subjetivos, como a competência do órgão que o editou - objetivos, como a forma, os prazos, o rito, observados em sua edição quanto dos requisitos substanciais - respeito aos direitos e garantias consagrados na Constituição de constitucionalidade do ato jurídico. ${ }^{1}$

Pinto Ferreira, por sua ve $z$, chega a ver na Constituição uma superlei com elevada força normativa, a qual seria perdida ante a ausência de um órgão para defendêla. ${ }^{2}$ Hans Kelsen, a seu turno, esclarece noção clássica sobre o controle:

A 'inconstitucionalidade' ou 'ilegalidade' de uma norma que, por um motivo ou outro, tem de ser pressuposta como válida significa, assim, ou a possibilidade

FERREIRA FILHO, Manocl Gonçalves. Curso de direito constitucional. 27. ed. atual. São Paulo: Saraiva, 200I. p. 34. Objctivando conferir maior precisão ao conceito esboçado pelo afamado professor, tem-se que a terminologia ato juridico se revela como imprópria para fins de determinação do objeto do controle de constitucionalidade em sentido estrito. Este tem por fim o exame da conformidade da lei ou ato normativo proveniente do Poder Público com a Constituição, não sendo alvo de fiscalização os atos de natureza privada (cf., acerca. BASTOS, Celso Ribeiro. Comentários à Constituição do Brasil: promulgada em 5 de outubro de 1988. volume 4 - arts. 92 a 126. São Paulo: Saraiva, 1997. p. 130). Logo, o termo ato juridico abrange uma séric de atos da esfera particular que se encontram alheios ao controle, tais como os negócios jurídicos, por exemplo, sendo oportuna a sua delimitaçào com a tinalidade de maior precisar o conceito.

2 FERREIRA, Pinto. Cirso de direito constrtucional. 8. ed. ampl. e atual. de acordo com as Emendas Cunstitucionais e a Revisão Constitucional. São Paulo: Saraiva, 1996. p. 421. 
de esta ser anulada (do modo ordinário, se for uma decisão judicial, de outro modo, que não o ordinário, se for um estatuto), ou a possibilidade de ser nula. Sua nulidade significa a negação da sua existência pela cognição jurídica. Não pode ocorrer qualquer contradição entre duas normas de diferentes níveis da ordem jurídica. A unidade da ordem jurídica nunca pode ser ameaçada por qualquer contradição entre uma norma superior e uma inferior na hierarquia do Direito. ${ }^{3}$

Gilmar Ferreira Mendes aponta, por sua vez, seguindo a lição de Orlando Bitar na temática, ser a inconstitucionalidade a não-conformidade da lei ou ato normativo com a Constituição, conjugada com a sanção ${ }^{4}$ (nulidade/anulabilidade) incidente por conta desta desconformidade." Clèmerson Merlin Clève assevera, igualmente, poder ocorrer a inconstitucionalidade no caso de desconformidade do ato normativo ou do seu processo de elaboração com a Carta Maior ${ }^{6}$

Cretella Júnior estabelece ligação intima entre a rigidez constitucional e o advento do controle, ao prenunciar que este “(...) é o procedimento - existente nos paises de ('onstituição rigida - que incide sobre determinadas normas, para, examinando-lhes os requisitos formais e materiais, verificar se estas normas são ou não são compativeis com a Constituição vigente" '

A relação entre o controle constitucional e a supremacia da Carta Maior também resultou admitida por Afonso Arinos de Mclo Franco, ${ }^{x}$ ao preceituar quais os mecanismos de defesa da Constituição:

A esta técnica da limitação do poder, através da submissão dos poderes instituidos à supremacia da Constituição, é chamada controle constitucional, e visa assegurar, por

" KELSEN, Hans. Teoria geral do direito e do estado. Tradução Luis Carlos Borges. 3. ed. São Paulo: Martins Fontes. 1998. p. 233.

- Acerca da ameaça de sanção como sendo parte da norma no seu aspecto dialógico, conferir FERRAZ JR., Tércio Sampaio. Teoria da norma juridica: ensaio de pragmática da comunicação normativa, p. 73: "Na realidade, a ameaça de sanção faz parte da norma no seu aspecto dialógico e não no seu aspecto monológico. Neste sentido, ela é argumento de persuasào, consistindo para o endereçado - o sujeito normativo . uma indicação do comportamento do editor - a autoridade - em determinadas circunstâncias" Serve a sanção como instrumento da manutenção de autoridade e à sua suspınsão provisória (cf. p. 75).

s MENDES, Gilmar Ferreira. Controle de constitucionalidade: aspectos juridicos e politicos. São Paulo: Saraiva, 1990. Titulo I - Constituição. constitucionalidade e inconstitucionalidade.

- CLĖVE, Clèmerson Merlin. A fiscalização abstrata de constinucionalidade no diruito brasileiro. São Paulo: Revista dos Tribunais, 1995. p. 30.

7 CRETElla JÚNIOR, José. Elementos de direito constilucional. 2 ed. rev. São Paulo: Revista dos Tribunais, 1998. p. 94. Celso Ribeiro Bastos assevera, a seu turno que o conceito de inconstitucionalidade se apresenta vazio de qualquer conteúdo nos países em que se adota a flexibilidade constitucional. vinculando a presença do controle, necessariamente, à presença de uma Constituição rigida (Cf. BASTOS. Celso Ribeiro. Comentários à Constituição do Brasil: promulgada em 5 de outubro de 1988. volume 4 arts. 92 a 126. São Paulo: Saraiva, 1997. p. 134).

s FRANCO, Afonso Arinos de Melo. Direito constitucional: teoria da Constituição; as Constituições do Brasil. Rio de Janciro: Forense, 1976. p. 139. 
vários mecanismos, a supremacia material e formal da Constituição sobre as leis e os atos do governo e da administração.

Do quanto visto, nota-se que a doutrina vê o controle de constitucionalidade como sendo a análise de adequação entre leis e atos normativos do Poder Público e a Constituição Federal, funcionando, portanto, como instrumento de aferição da congruência de atos que possuam teor normativo perante os ditames insculpidos na Carta Magna.'

Feita esta breve introdução, seria oportuno saber os caracteres atuais do sistema de controle na Constituição, de $1988,^{10}$ sendo possível dizer que, com ela, vivese, na atualidade, o apogeu do controle de constitucionalidade, em virtude da alta complexidade alcançada pelo sistema pátrio, que compreende:

a) controle incidental (por via de exceção/defesa, ou concreto): exercitável por qualquer juiz ou tribunal, diante de um caso concreto, tendo como origem, historicamente," a famosa decisão proferida, em 1803. pelo Juiz norteamericano Marshall no caso Marbury vs Madison. Neste controle, a decisão proferida tem efeitos incidenter tantum, afastando-se do caso sub judice a aplicação da norma incompatível, mas mantendo-a intacta no ordenamento. Nos tribunais, ${ }^{1 ?}$ aplica-se a cláusula da reserva de plenário

- O controle de constitucionalidade serve, saliente-se, como mecanismo que preserva u próprio regime democrático, como realça o professor Elival Ramos: “(...) o combate à inconstitucionalidade é ainda mais vital nos Estados em transformação, dependendo do seu sucesso o triunfo da Democracia c do desenvolvimento com justiça social" (RAMOS, Elival da Silva. A inconstitucionalidade das leis: vício e sanção. São Paulo: Saraiva, 1994. p. 22I).

to Após a superação de um dificil periodo ditatorial, a Constituição de 1988 representa momento de relevância impar para o pais, por se tratar da primeira Carta que não se originou de uma ruptura nas instituições (C'f. BONAVIDFS, Paulo. Históric constitucional do Brasil. 5. ed. Brasilia: OAB Editora, 2004. p. 455). Ressalte-se ser, segundo as liçōes do mencionado professor, a hora de fazer navegar $o$ barco constitucional. o que se espera ser cada vez mais alcançado em nosso pais (Cf. BONAVIDES, Paulo. A constituição aberla. Belo Horizonte: Del Rey, 1993. p. 246).

"Para aprofundar o entendimento histórico do surgimento do controle incidental, cf: BITTENCOURT, Carlos Alberto Lúcio. O Controle Jurisdicional da Constitucionalidade das Leis. 2 ed. Brasilia: Ministério da Justiça, 1997. Capitulo 1.

12 Cr. THEOdORO JÚNIOR, Humberto. Curso de Direito Processual Civil. 32. ed. Rio de Janeiro: Forense, 2000. v. 1. p. 571 . Através do quadro elaborado pelo professor, descobrem-se quais os meandros da fiscalização no bojo dos tribunais. Após ser fcita a argüição de inconstitucionalidade e ser ouvido o Ministćrio Público, o relator submetc a qucstão, como prcliminar, ao órgão que deve julgar o processo, tendo estc duas escolhas: rejeirar a alegação. o que conduz à não suspensão do julgamento, ou aceitar a alegação, quando ocorre a suspensão do julgamento para que a questão seja submetida ao Pleno ou Órgão Especial equivalente. Seja rejeitando, seja declarando a inconstitucionalidade, os autos retomam ao órgão primitivo, prosseguindo, entāo. o julgamento que estava sendo rcalizado. Incumbe lembrar, igualmente, da sua advertência, ao prelecionar que: "Se a questão de inconstitucionalidade já houver sido decidida anteriormente pelo colegiado ou pelo Supremo Tribunal Federal, não é necessário reiterá-la em cada novo caso que verse sobre a mesma matéria. Os órgãos fracionários, a que couber a competência para o recurso ou a causa. proferirão o julgamento, sem suscitar o incidente do art. 480 (Lei n. 9756. de 17.12.98)" (cf. p. 568). 
para declaração de inconstitucionalidade (art. 97 da Constituição de 1988), exigindo-se, pois, maioria absoluta. Ademais, participa o Senado Federal do aludido controle. na medida em que pode resolver expurgar, definitivamente, a norma declarada inconstitucional pelo STF, ${ }^{13}$ retirando-a do conjunto legislativo pátrio. Respeitadas as regras de jurisdição e competência, são cabiveis, no objeto do controle incidental, quaisquer espécies de leis (federais, estaduais, municipais) que estejam em desacordo com a Carta Magna, havendo, como regra, a conferência de efeitos ex tunc (retroativos) à decisão empreendida.

b) controle principal (por via de ação, ou abstrato): exercitável mediante as ações previstas constitucionalmente. as quais objetivam atacar frontalmente (principaliter) a norma inconstitucional, retirando-a do ordenamento juridico, com eleitos ex nunc ou ex tunc. Teve como marco a influência kelseniana quando da elaboração da Constituição Austriaca de $1920 .^{14}$ Há, no Brasil pós-88, diversos mecanismos que permitem o exercício da fiscalização abstrata, sendo espécies a Ação Direta de Inconstitucionalidade (ADIN), a ADIN por omissão - a qual configura-se, inclusive, como criação da Carta de 1988; a Ação Declaratória de Constitucionalidade (ADC), advinda com a Emenda Constitucional n. 3/93, e a Argüição de Descumprimento de Preceito Fundamental (ADPF), contemplada, também. no próprio texto da Constituição cidadã. Ampliou-se a legitimação para deflagração do controle abstrato brasileiro (art. 103), bem como foi assegurada a possibilidade de instituição, pelos Estados. dos seus regimes próprios de fiscalização constitucional (art. 125, $\S 2^{\circ}$ ). Ademais, previu-se a participação do Advogado Geral da União nos processos de aferição de constitucionalidade, aliada à manifestação do Procurador Geral da República.

Estando firmadas as principais características do atual regime brasileiro de controle de constitucionalidade, impende perscrutar, com mais atenção, quais são as principais características do Município em nossa órbita federativa.

13 O Regimento Interno do Supremo Tribunal (RISTF) disciplina o processamento da verificação, sendo oportuno destacar, de logo, a exigência de quorum de 8 ministros. sendo exigida a maioria de 6 para a declaração.

It Para uma melhor compreensão dos caracteres do controle, cf.: DANTAS, Ivo. O valor da constituiçaau: do controle da constitucionalidade como garantia da supralegalidade constitucional. 2 ed. rev. aum. Rio de Janeiro: Renovar, 2001. p. 65. 
3. O Município como ente federativo: singularidade nacional

O Município nasceu, conforme a história nos ensina, em Roma. ${ }^{15}$ representando, à época, um título privilegiado concedido às cidades que vieram a ser conquistadas pelo Exército romano. Neste sentido, são lapidares as palavras de José Nilo de Castro:

O Município aparece mesmo em Roma, como título concedido a certas Cidades conquistadas pelo Exército Romano. Eis que os vencidos. os povos vencidos, ficavam sujeitos, desde a derrota, às imposições do Senado Romano. Iintretanto, em troca da sujeição alvitrada, e obedientes às leis romanas, concediam-se-lhes privilégios. prerrogativas, como o direito de continuarem a praticar o comércio e sua vida civil, o de escolherem os seus representantes, a dirigirem-lhes as próprias Cidades, repetese, subordinadas todas à Roma. De conseqüência, as comunidades que recebiam essas vantagens chamavam-se Municípios, isto é, Múnus, eris, quer dizer, na lingua latina, dádivas, privilégios e capere (capio, is, cepi, captum, ere), verbo latino que significa receber. Daí, o Municipio etimulugicamente explicado aquela entidade que recebeu privilégios. ${ }^{16}$

No Brasil, após a criação pioneira do Municipio de São Vicente, ${ }^{17}$ muitos outros vieram a surgir no cenário nacional, contribuindo. paulatinamente, para que se alcançasse a quantidade atual, a qual totaliza número superior a cinco mil entes desta natureza.

Vale destacar, no particular, que o Município assume importância especial para o sujeito que nele habita. A vida de cada ser humano nele diuturnamente se desenrola, ai estando presentes us momentos mais significativos e marcantes de cada vivência particularizada. De fato, a relação de pertencimentes de cada pessoa ao campo

is Neste sentido. conferir ISERN, Luiz, Francisco. Controle de constitucionalidade por meio do veto mumicipal. São Paulo: Método, 2002. p. 154: "Embora Roma tivesse ignorado, durante largo tempo, a instituição municipalista (durante duzentos anos de Monarquia e quinhentos de República desconhece o regime municipal), surgiu ele naquele Estado. Atribui-se a Sy/a a origem das práticas municipalistas"

16 CASTRO, José Nilo de. Direito municipal positivo. Belo Horizonte: Del Rey, 1991. p. 16 (Grifos no original). Cumpre explicitar, outrossim, a vinculação da cidade ao conceito de sociedade politica. consoante já lecionava Aristóteles: "Sabemos que uma cidade é como uma associação, e que qualquer associação é formada tendo em vista algum bem; pois o homem luta apenas pelo que cle considera um bem. As socicdades. lodas elas, portanto, propõem-se algum lucro - especialmente a mais importante de todas. visto que pretende um bem mais elevado, que envolve as demais: a cidade ou sociedade política" (Cf. ARISTÓTELES. Politica. São Paulo: Martin Claret, 2004. p. II).

17 CASTRO, José Nilo de. op. cit. p. 37. O autor menciona que, em seguida à criaçãu de São Vicente (22/01/1532). advieram os Municipios de Olinda (1537). Santos (1545). Salvador (1549). Santo Andri da Borda do Campo (1553) e Rio de Janeiro (1567). 
municipal se deflagra de maneira clara, costumeiramente mais pronunciada do que aquela que se verifica no relacionamento do cidadão com o Estado ou com a União. Há, portanto. e em regra, maior proximidade afetiva do sujeito perante o Município em que vive. $^{18}$

No âmbito nacional, o referido ente nunca desfrutou da mesma liberdade e autonomia de atuação como a partir da Constituição vigente. De fato, a Constituição de 1988 engendrou solução no mínimo original ${ }^{19}$ no âmbito do entendimento tradicional do que poderia ser imaginado como forma de Estado: alçou o Município à condição de ente federativo, dotando-lhe de características outrora não-ostentadas.

O Estado Federal, concepção originada, com primazia, no âmbito do constitucionalismo norte-americano ${ }^{20}$ revela-se como forma de Estado em sede da qual

1. Partilhando do mesmo entendimento, cf. ISERN, Luiz Francisco. op. cit. p. 161: "Inicialmente, cumpre ressaltar a importância, sempre verificada, do componente fisiográfico para a constiluição de uma comunidade. O Município é o local onde o cidadão mora, unde é conhecidu e onde se deixa conhecer. Para essa comunidade ele mostra a faceta social da sua personalidade, exibe status. espera reconhecimento e apreço. É o local em que educa seus filhos e para isso assume posturas defunidas. É o local a que dedica o seu bem-querer, o que lhe serve de estímulo para contribuir. Suas decisões, pois, são tomadas com base em afinidades adquiridas, para um grupo com o qual ele tem empatia, simpatia ou até mesmo antipatia. Em suma, o municipe é o Município, e o Município é o munícipe. Ai reside a importância do Municipio para a pessoa. É ali que as coisas verdadeiramente importantes para ela acontecem"

19 Neste sentido, vejamos o entendimento de Luiz Francisco Isern: "Os Municípios recebem destaque na Constituição Federal de 1988, notadamente porque se colocam na curiosa situação de não possuirem similar em todo o mundo. Queremos dizer que o Municipio desfruta no Brasil de posição inexistente em outros países. Aqui ele é tido como ente integrante do pacto federativo. No resultado final, lal circunstância significa que o Municipio é pessoa política autônoma, do mesmo modo que os demais entes politicos (a União e os Estados). A soma desses cntes políticos é que caracteriza a nossa Federação" (ISERN, Luiz Francisco. up. cit. p. 162).

$\therefore$ Mas que nele não encontra, de forma absoluta, a totalidade de suas origens, como acentua o professor Saulo Casali; Cf. BAHIA, Saulo José Casali. A federação brasileira. Revista Juridica dos Formandos em Direito da UFBA, p. 184. Indispensável destacar. também, a contribuição trazida pelo professor Loewenstein quanto às origens do federalismo: "Junto a la constitución escrita y el establecimento de la forma republicana de gobierno, esto es, no monárquica, en Estados com um extenso territúrio, el federalismo es la aportación americana más importante a la leoria y a la práctica del Estado moderno. Uniones de Estados de tipo federal habian cxistido anteriormente: en la antigua Grécia, las ligas o sinoikias délica, anfictiónica, helénica y aquea; la "alianza eterna" (ewige Bund) de los cantones suizos desde el siglo XIV y XV, la Unión de Litrecht (1569) entre las siete provincias norteñas de los Paises Bajos. Pero ninguna de estas formaciones constituyeron un auténtico Estado federal. en parte por la ausencia de órganos comunes con jurisdicción directa sobre los ciudadanos de los Estados asociados y en parte por la preponderancia de uno de los micmbros" (LOEWENSTEIN, Karl. Teoria de la constitucion. Traducción y estudio sobre la obra por Alfredo Gallego Anabitarte. Barcelona: Ariel, 1964. p. 354 355)(grifos nossos). 
são consagrados círculos de autonomia ${ }^{21}$ para os entes constitutivos, ${ }^{22}$ prevendo-se, em sede normativa, competências individualizadas para cada um deles, e assegurando-se sua participação na expressão na vontade do todo composto.

Ao longo de sua evolução, a noção de Estado Federal sofreu mudanças, sujeitando-se a modificações. No entanto, podem ser inferidas algumas características específicas que contribuem para corroborar a natureza federal de determinado ente estatal, sendo bastante proveitosa, no particular, a lição de Michel $\operatorname{Temer}^{23}$, para o qual haveria:

a) notas essenciais à caracterização federal: repartição constitucional de competências; participação da vontade das ordens jurídicas parciais na vontade criadora da ordem jurídica nacional; e possibilidade de autoconstituição. consubstanciada na existência de Constituições locais.

b) elementos indispensáveis para mantença da federação: rigidez constitucional e a existência de um órgão incumbido do controle de constitucionalidade das leis.

Avulta de importância destacar a histórica distinção ${ }^{24}$ manifestada na divisão entre leis de autonomia e leis de participação como caracteres do Estado federal, elementos que colaboram para que se compreenda a formulação original do referido conceito. $^{25}$

O modelo federativo nacional do pós- 88 inova, ${ }^{26}$ dessa forma, ao consagrar uma terceira entidade federativa, fugindo do modelo dual básico, o qual concebia, tão-somente, os Estados-membros e a União Federal como componentes da

21 Acerca da importância da noção de autonomia na formação da federação, cf. TEMER, Michel. Elementos de direito constitucional. p. 61: "Em face da idéia de soberania ressalta a concepção da unidade estatal. Por isso. no plano internacional não tem relevo o saber se a forma de Estado é federal ou unitária. Diante da idéia de autonomia a importanncia da distinção é inquestionável. É que ela só se encontra onde tiver sede a descentralização política (grau máximo) geradora de dominios parcelares da ordem estatal que, reunidos, formam a unidade".

22 FRIEDE, Reis. Curso Analitico de Direito Constitucional e de Teoria Geral do Estado. Rio de Janeiro: Forense, 1999. p. 120: "O Fstado Federal é. por definição, aquelc onde estão asseguradas, pela Constituição, autonomia politico-administrativa às partes descentralizadas (Estados-membros, Provincias, Territórios etc.). É, nesse sentido. reputada, pela quase unanimidade dos autores, como a forma mais moderna de Éstado" (grifos no original).

23 TEMER, Michel. Elementos de direito constitucional. 12. ed. São Paulo: Malheiros, 1996. p. 63.

24 BONAVIDES, Paulo. Ciência politica, p. 181. referindo-se, no caso, à noção construida por Georges Scelle.

25 BONAVIDES, Paulo. Ciência politica, p. 188-189: I:m sua evolução, o professor demonstra ter havido a predominância, a princípio. da autonomia dos entes constitutivos, alcançando-sc, em seguida, certo equilibrio de atuação, para se ver. na atualidade, a predominância do campo da parricipação dos referidos entes, percebendo-se, de forma correlata. "(...) considerável atenuação e declinio da autonomia"

26 Cf. SILVA, José A fonso da. O município na Constituição de 1988. São Paulo: Revista dos Tribunais, 1989. p. 7: "A Constituição de 1988 mudifica profundamente a posição dos Municípios na Federação, porque os considera componentes da estrutura federativa" 
aludida forma estatal. E o faz, de forma mais pronunciada, em três momentos: em seus artigos $1^{0},{ }^{27} 18^{28}$ e $29 .{ }^{29} \mathrm{Na}$ esfera legislativa, compete aos Municípios, doravante, legislar sobre assuntos de interesse local ${ }^{30}$ (art. 30, inciso I, da Constituição de 1988).

Alexandre de Moraes corrobora tal entendimento, ao concordar com a inclusão do Municipio na Federação, integrando-o “(...) na organização políticoadministrativa e garantindo-lhe plena autonomia (...)" ${ }^{31}$ Fernanda Dias Menezes de Almeida também concorda com a opção do Constituinte. ${ }^{32}$ Ademais, Regina Ferrari, a seu turno, explicita a dignidade possuída pelo Município perante as outras ordens federativas, ao lecionar que:

Um dos traços característicos de nossa Federação é a inclusão do Município como parte integrante do Estado Federativo do Brasil, reconhecendo, assim, que ele tem a mesma dignidade da União e dos Estados-Membros, compartindo o exercício de sua soberania entre três ordens jurídicas diferentes. ${ }^{33}$

A solução constitucional não foi aceita, entretanto, de forma pacífica pela doutrina. Cabe destacar, por exemplo, as críticas severas do professor Raul Machado Horta, para o qual a concepção do Município como ente federativo revela regra de federalismo assimétrico ${ }^{34}$ da Constituição de 1988, asseverando que: "O Estado Federal é uma federação de Estados e não, de Estados e Municipios" ${ }^{35}$ No mesmo sentido. José

2. Tal dispositivo insere, expressamente, os Municipios, junto aos Estados, como componentes da República Federativa do Brasil.

28 Além de inserir os Municípios no rol da organização politico-administrativa da Rupública Federativa do Brasil, salienta a autonomia por eles ostentada. José Afonso da Silva. op. cit. p. 8, a seu turno, divide a autonomia municipal nas capacidades de uuto-organização (elaboração de lei orgânica própria), uutogoverno (eletividade de Prefeito e Vereadores), capacidade normativa própria (referente à autolegislação) e capacidade de auto-administração.

29 O ruferido dispositivo evidencia a capacidade normativa própria municipal, a qual é exercida pela elaboração de sua Lei Orgânica.

30 O professor Celso Bastos defende a elasticidade do conceito de interesse local como uma caracteristica vantajosa da referida definição. (Cf. BASTOS, Celso Ribeiro. Curso de direito constitucional, cit., p. 311 ).

31 MORAES, Alexandre de. Direiro constitucional. 12. ed. São Paulo: Atlas, 2002. p. 273 ن 274.

32 ALMEIDA, Fernanda Dias Menezes de. Competências na Constituição de 1988. 3. ed. São Paulo: Atlas, 2005. p. 112 : 162.

33 FERRAR, Regina Maria Macedo Nery. A Inconstitucionalidade da Lei Mhunicipal. Curitiba: Juruá. 1991. p. 32.

34 O federalismo assimétrico seria uma forma anômala de federalismo, a qual pode "(...) localizar-se no fenômeno fático, por deformação de institutos federais, como no ato normativo, mediante a criação de soluções autônomas, oferecidas pela norma juridica" (v. HORTA. Raul Machado. Direito constitucional, p. 495).

35 HORTA, Raul Machado. Direito Constitucional. 4. ed. rev. e atual. Belo Horizonte: Del Rey, 2003. p. 497. Vale ressaltar, igualmente, o seguinte trecho: "A Constituição Brasileira consagtou assimetria que não obteve adoção em outro texto do federalismo constitucional cuntemporâneo" 
A fonso da Silva proclama não ser o Municipio unidade federada, ${ }^{36}$ assim como José Nilo de Castro ${ }^{37}$ e Saulo Casali Bahia. ${ }^{38}$

No entanto, revela-se acertada a escolha do Constituinte pátrio ao arrolar os Municípios como partes integrantes do modelo federativo. Isto porque não se pode encarar um instituto jurídico como refém absoluto do tempo, condenando-o à completa paralisia diante das inúmeras evoluções que ocorrem no contexto que o circunda. Por óbvio, o conceito de Estado federal não pode se afastar de tal regra, sendo oportuno atualizá-lo e enriquecê-lo com a incorporação de mais uma esfera constitutiva, solução que merece destacado aplauso.

Fala-se, pois, numa Federação brasileira de duplo grau ${ }^{39}$ dotada de singularidades ante o modelo tradicional, é verdade, mas as quais não colaboram para desmerecer a inclusão na noção federativa. Neste sentido, filiamo-nos à doutrina clássica de Hely Lopes Meirelles, para o qual:

A Federação brasileira não dispensa nem prescinde do Municipio na sua organização constitucional. Segue-se, dai. que o Município brasileiro é entidade politico administrativa de terceiro grau, na ordem descendente da nossa Federação: União - Estados - Municípios (...) Em todas as edições anteriores sustentamos que o Município brasileiro sempre fez parte da l'ederação. F, agora, a Constituição de 1988 assim o declarou em seus arts. $1^{\circ} \mathrm{e}$ 18, corrigindo essa falha. ${ }^{40}$

36 SILVA, José A fonso da. Curso de direito constitucional positivo, cit., p. 620: “"(..) a lederação brasileira adquirc peculiaridade. configurando-se, nela, realmente três esferas govenamentais: a da Uniăo (governo federal), a dos Estados Federados (govemos estaduais) e a dos Muricipios (governos municipais), além do Distrilo Federal. a que a Constituição agora conferiu autonomia. E os Municipios transformaram-se mesmo em unidades federadas? A Constituição não o diz. Ao contrário. existem onze ocorrências das expressões unidade federada e unidade da Federação (no singular ou no plural) rufurindo-sc apenas aos Estados e Distrito Federal, nunca envolvendo os Municipios"

37 Neste mesmo sentido, para José Nilo de Castro: "A Federação, dessarte, não é de Municípius e, sim, de Estados. cuja caracterização se perfaz com o exercitamento de suas leis fundamentais, a saber. a da autonomia e a da participação" (Cf. ( "ASTRO, José Nilo de. op. cit. p. 37 (Negrilus no original).

¿ BAHIA, Saulo José Casali. op. cit. p. 202: "Restrito, assim, a temas locais, o Municipio desenvolve, no Brasil, atividade administrativa e legislativa (nunca judiciária) que não se presta a elevá-lo ao grau de entidade federada, na medida em que não participa, de qualquer modo efetivo, da direção dos negócios politicos nacionais. Sua posição. então é idêntica àquela possuida pelas células municipais da maioria dos Estados reconhecidamente unitários, que quase sem exceção mereceram a possibilidade de legislar e administrar no àmbito local"

39 Cf. ALMEIDA. Fernanda Dias Menezes de. op. cit. p. 113: "Assim. o federalismo brasilciro cortesponde ao que CHARLES DURAND denomina lederalismo de duplo grau, caracterizado pelo fato de que não só o Estado-membro. mas tambèm o ente politico local, possui competência è autonomia irredutiveis. salvo por emenda constitucional"

to MEIRELLES, Hely Lopes. Direiro municipal brasileiro. 7. ed. atual. Por Izabul ( amargo Lopes Monteiro e Yara Darcy Police Monteiro. São Paulo: Malheiros. 1994. p. 39. Ademais, não se pode olvidar o ensinamento de Victor Nunes Leal (Apud ROCHA, Fernando Luiz Ximenes. Controle de constitucionalidade de leis municipais. Cf. Capitulo 8 , em especial), quando preceitua inexistirem duas 
Após corroborar, pois, a inclusão do Município com ente federativo, incumbe perquirir quais as formas possíveis de controlar o produto da capacidade normativa municipal, a saber, suas leis e demais atos normativos.

4. O controle incidental das leis municipais

No que tange ao controle empreendido no campo incidental, sabe-se haver ampla possibilidade de aferição de constitucionalidade da lei diante da Carta Magna, cabendo a todos os órgãos jurisdicionais a realização do referido controle difuso. No âmbito específico da lei municipal, não há diferença para a amplitude do que ocorre no controle em geral: qualquer lei ou ato normativo expedido na órbita municipal que esteja em desacordo com a Lei Maior pode ser declarado inconstitucional por qualquer dos órgãos que compõe o Poder Judiciário brasileiro.

Todavia, diferem os meandros processuais plausiveis de utilização em razão da lei utilizada como parâmetro. Com efeito, a lei municipal pode: ferir comando esculpido na Constituição Estadual; descumprir disposição prevista na Constituição Federal ou, também, estar em desacordo com ambos os diplomas ocasião manifestada no caso de haver norma constitucional federal repetida no campo da Lei Maior Estadual.

No primeiro caso, a ofensa deve ser dirimida, exclusivamente, no campo do Estado-membro. Sabe-se, à evidência, que resultou assegurada, pelo Constituinte, a autonomia do Estado na formulação de seu microssistema de controle de constitucionalidade, ${ }^{41}$ cabendo-lhe, também, elaborar sua Carta Maior, como manifestação do seu Poder Constituinte Decorrente. ${ }^{42}$ Caso ocorra antinomia entre a norma municipal e a norma estadual, o conflito deve ser dirimido entre ambos, não devendo ser provocado o Supremo Tribunal Federal para tomar parte na discordância, mostrando-se indevido, pois, o uso do recurso extraordinário. ${ }^{47}$ Preserva-se, desta forma, a normatividade autônoma do Estado-membro. ${ }^{44}$

federações exatamente iguais.

4. Expressão empregada por Celso Ribeiro Bastos: Cf. BASTOS, Celso Ribeiro. Comentários à Constituição de 1988: promulgada em 5 de outubro de 1988, cit., p. 148.

$₫ 2$ FERraz. Anna Cândida da Cunha. Poder constituinte dos éstados-membros. São Paulo: Revista dos Tribunais, 1979. p. 58: "Quando a função constituinte dirige-se à estruturação e organização do EstadoMembro, ou seja, a institucionalização da ordem jurídica interna de uma unidade federada, surge o chamado Poder Constituinte Decorrente institucionalizador ou inicial; quando esse Poder atua para modificar a sua obra primeira, veste o nome de Poder Constituinte Decorrente de Revisão Estadual"

4) FERRARI, Regina de Macedo Nery. A Inconstitucionalidade da Lei Municipal, cit., p. 89.

4 BASTOS, Celso Ribeiro. O controle judicial da constitucionalidade das leis e atos normativos municipais. cit., p. 71: "No que respeita ao método "difuso", há que se distinguir a argüição de inconstitucionalidade face à Constituição Federal e à Constituição do Estado-membro. Assim. pois, no caso de a lei municipal afrontar a Constituição Federal c impugnada na "via de exceção". das decisões dos tribunais locais caberá apelo ao Supremo Tribunal Federal, atendidos os pressupostos de cabimento do recurso extraordinário, 
$\mathrm{Na}$ segunda hipótese, ou seja, caso haja incompatibilidade entre lei municipal e a Constituição Federal, incumbe utilizar o recurso extraordinário para fazer chegar a questão constitucional à apreciação do Pretório Excelso. ${ }^{45}$ A Carta Magna instituiu hipóteses restritivas para o cabimento do referido recurso, vinculando sua admissibilidade à alegação de violação da Lei Maior.

$\mathrm{Na}$ terceira hipótese, a saber, em sendo constatada lei municipal que fira, simultaneamente, a Constituição Estadual e a Constituição Federal, pode-se alegar, tanto no Tribunal de Justiça quanto no Supremo, a violação, sendo possível o emprego do recurso extraordinário caso haja inconformismo com a decisão prolatada na órbita estadual, já que se trata de dupla esfera normativa questionável.

Ante o exposto, nota-se ser claramente possível o exercício do controle incidental de constitucionalidade de leis municipais, seja quando o parâmetro for a Constituição Estadual, seja quando resultar questionada a congruência normativa com a Carta Federal. Impende salientar, contudo, que, no caso de violação simultânea, persistirá a possibilidade de emprego de recurso extraordinário para o Supremo Tribunal Federal.

5. O controle principal das leis municipais e sua parametricidade

5.1. A lei municipal e a Constituição Estadual

Sabe-se ser possível a realização do controle abstrato de constitucionalidade de leis e atos normativos municipais que ofendam a Carta Magna estadual, solução que se impõe por força da prescrição constante no art. $125, \S 2^{\circ}$, da Constituição, de 1988.

Com efeito, afigura-se correta a consagração esposada pelo Constituinte, em razão de se conferir a devida atenção para o eixo autônomo de normatividade que existe no campo dos Estados-membros. Seria postura condenável se acaso o legislador permitisse a elaboração de Constituições Estaduais alvo de fácil descumprimento pelos entes municipais, possibilitando, desse modo, que prevalecesse o arbitrio desmesurado nesse campo, permitindo normatividade desprovida da sanção adequada.

Em momento anterior ao advento da atual Carta Magna, a doutrina já propugnava a instituição de controle abstrato de leis municipais tendo como parâmetro a

consoante o item III e alineas do art. 119. da C.F., e, também, as hipóteses contidas no Regimento Intemo do STF. No entanto. ocorrendo exclusivamente a violaçāo da Constituição do Estado-membro por lei ou ato normativo municipal, as decisões dos órgãos judiciais inferiores serão apreciados tão-somente pelo Tribunal de Justiça"

t5 FERRARI, Regina de Macedo Nery. A Inconstitucionalidade da Lei Municipal, cit., p. 86. 
Constituição Estadual. Neste sentido, importa citar antigo entendimento do professor José Afonso da Silva:

É fora de dúvida, portanto, que existe relação hierárquica entre leis e atos municipais e a Constituição do Estado. Se assim é, torna-se incompreensível sustentar que essas leis e atos só se expõem ao controle da jurisdição excepcional nos casos adrede indicados na Constituição Federal, negando-se, por esse modo, ao constituinte estadual o poder de instituir sistema próprio de defesa de Constituição estadual, como se o sistema de defesa desta fosse matéria de competência do constituinte federal. ${ }^{46}$

Fernando Luiz Ximenes Rocha ${ }^{47}$ contribui de forma destacada para sintetizar a abordagem do tema no momento em que leciona o entendimento do controle incidental (difuso) da lei municipal. Segundo ele:

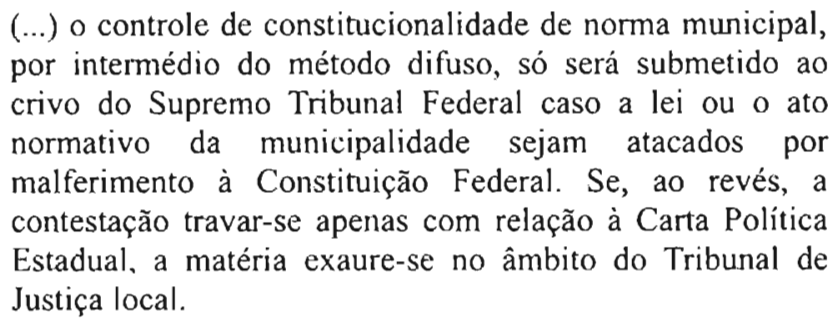

Também antes do surgimento da Carta de 1988, interessante polêmica acerca dessa espécie de conflito ocorreu no Estado de São Paulo, por ocasião do discutido art. 50, parágrafo único, da Constituição Estadual, o qual veio a instituir, sem autorização expressa da Constituição Federal vigente (1967), a possibilidade de utilização de representação de inconstitucionalidade de leis municipais no campo do Estado-membro.

O tema foi intensamente discutido quando da propositura das Representações ns. 261.928 e 261.929 , tendo sido julgado procedente, no primeiro processo, o pedido de declaração de inconstitucionalidade da Lei n. 8.550/76 do Município de São Paulo. Todavia, no curso do processo, advieram inúmeras discussões acerca da legitimidade do ente estadual para proceder à instituição autônoma de sistema de controle de constitucionalidade, as quais foram superadas com a prolação do acórdão que sufragou a tese defendida na inicial. ${ }^{48}$

:- SILVA, José A fonso. Ação direta de declaração de inconstitucionalidade de lei municipal, cit., p. 100.

- ROCHA, Fernando Luiz Ximenes. Controle de constitucionalidade de leis municipais. São Paulo: Atlas, 2001. p. 96.

48 Cf., em especial: Ação direta de controle da constitucionalidade de leis municipais em tese. cit., p. 21 (petição inicial); p. $37-42$ (manilestação do Ministério Público argüindo preliminares de ilegitimidade ativa e incompetência do Tribunal de Justiça); p. $45-48$ (impugnação às preliminares); p. 135-174 (acórdão do Pleno do TJ-SP). 
No Rio Grande do Sul a temática também foi alvo de debates, os quais vieram a lume, de forma destacada, nas seguintes Representações:

N. 19.522 - foi conhecida a representação e julgado procedente o pedido de declaração de inconstitucionalidade dos artigos 12, I; 29; 36, parágrafo único e 43 da Lei Municipal n. 10, de 26/01/1972, do Municipio de Venâncio Aires, ${ }^{49}$

N. $21.430 \cdots$ decretada a inconstitucionalidade da Lei $n .{ }^{\circ}$ 2649, de 27.06.1973, do Município de Rio Grande;";"

N. 21.431 - decretada a inconstitucionalidade do art. 18. parte final, e seus parágrafos $1^{\circ} \mathrm{c} 2^{\circ}$, da Lei Orgânica do Município de Ijui. ${ }^{\text {ji }}$

$\mathrm{Na}$ órbita do Direito Constitucional hodierno, não há, no entanto, maiores questionamentos acerca do tema, em virtude do conteúdo da nova Lei Maior. Resulta permitida, dessa forma, a aferição da compatibilidade de leis municipais tendo por parâmetro a Constituição Estadual, questão cuja competência para processamento e julgamento cabe ao Tribunal de Justiça respectivo. Há, contudo, quem chame atenção para a relativa desimportância do constitucionalismo estadual, constatação que conduz à falta de maiores empolgações pela temática. ${ }^{52}$

\subsection{A lei municipal e a Constituição Federal}

Vicejam diversas controvérsias a respeito do conflito existente entre a lei municipal e a Constituição Federal. O problema, fundamentalmente, se relaciona com a ausência de previsão expressa, no texto constitucional, da lei municipal como sendo integrante do objeto do controle de constitucionalidade operado no campo da fiscalização abstrata.

Consoante as lições já vistas, percebe-se que a Ação Direta de Inconstitucionalidade (ADIN) serve para a tutela da incongruência existente entre as leis federais e estaduais ante a Constituição, campo de abrangência parcialmente compartilhado pela Ação Declaratória de Constitucionalidade (ADC). Não se insere, entretanto, a lei municipal nesse rol.

\footnotetext{
$\therefore \quad$ Cf. SÃO PAULO (Estado). Procuradoria Geral. Ação direta de controle da constitucionalidade de leis municipais em tese. São Paulo: Centro de Estudos da Procuradoria (ieral do Estado. 1979. p. 247.

so Id. Ibidi., p. 259.

51 Id. Jbid., p. 261.

s2 Cf, a respeito: BARROSO. Luis Roberto. O controle de constilucionalidade no Direilo brasileiro: exposição sistemática da doutrina c análise critica da jurisprudència. São Paulo: Saraiva, 1994. p. 178.
} 
O tema foi alvo, então, de controvérsia doutrinária, formando-se duas correntes definidas a seu respeito: uma primeira que acreditava que a ausência do Texto teria sido intencional, revelando-se uma vontade inequivoca de empreender a exclusão da lei municipal da análise de conformidade; e uma sugunda corrente, que propugnava pela consagração da tese de que teria havido, em verdade, uma omissão do constituinte. o qual teria laborado em equívoco quando da construção de sua obra.

Desse modo, o debate sobre a compreensão do assunto oscilou entre a afirmação das citadas teses, firmadas na intencionalidade da exclusão ou na constatação de seu equivoco. Cumpre, pois, analisar brevemente os argumentos de cada uma das referidas linhas de pensamento.

Gilmar Ferreira Mendes pode ser apontado como um dos maiores defensores da primeira doutrina, ao prelecionar ter ocorrido, em verdade, uma deliberada demonstração do intento de excluir a lei municipal do objeto de controle.

Fxamina a existência de uma distinção entre lacunas autênticas (também conhecidas como de lege lata ou lacunas de formulação) - ou seja, aquelas que afetam a própria formulação da regra legal - e lacunas inautênticas (chamadas. também. de lacunas de lege ferenda ou lacunas axiológicus ou de valoração) - consequiências derivadas da própria intuição juridica.

Para ele. consagrar-se-ia, no caso, um verdadeiro silêncio eloyüente (beredies schweigen), expressão de origem alemã empregada em casos de manifesta vontade de excluir determinada previsão. Ao final, sintetiza assim sua exposição: “(...) a aparente omissão do legislador tem especial significado. traduzindo, em geral. a vontade de não facultar a instituição de determinados regimes ou sistemas, ou de vedar a adoção de determinadas práticas" $\$ 3$ Vale realçar. também, o significado do termo, trazido por Karl Larenz:"

Pero existe también un "silencio elocuente" de la ley. Cuando el BGB enumera en el $\$ 6$ determinadas causas en base a las cuales se puede incapacitar a una persona, ello significa también que nadie puede ser incapacitado en base a otras causas no mencionadas en la ley.

33 MENDES, Gilmar Ferreira. Controle de constitucionulidade: aspectos jurídicos e politicos. São Paulo: Saraiva, 1990. p. 317.

st LARENZ. Karl. Metodologia de la ciencia del derecho. Traducción de Enrique Gimbernat Ordeig. Barcelona: Ariel, 1966. p. 292. 
Militando exatamente no mesmo sentido, prevê Lenio Streck $^{\text {ss }}$ ser impossivel, diante da atual sistemática, contemplar a verificação de constitucionalidade de uma lei municipal tomando como parâmetro a Constituição Federal. Segundo ele:

(...) ocorre a impossibilidade de solução no plano do controle concentrado através de ADIn. em face de impossibilidade de o STF apreciar esse tipo de inconstitucionalidade, consoante silêncio eloquiente da Constituição Federal, ao não prever tal possibilidade.

Pode-se citar, ainda, o exemplo do professor Fernando Ximenes ${ }^{56}$ como sendo representativo de jurista afinado com esta corrente, quando preceitua:

(...) ao optar pela repetição do silêncio estampado na Carta pretérita, deixou clara sua vontade de só admitir, quando se cuidar de legitimidade de lei ou ato normativo municipal por contrariedade de ao Texto Supremo, o controle por via de exceção, que é próprio da atividade jurisdicional. não comportando natureza política.

No mesmo sentido, preconiza Zeno Veloso que “(...) a omissão das leis municipais, no Texto Magno, não deriva de uma lacuna, de um esquecimento, mas, ao contrário, foi proposital, consciente, derivada de imperativos práticos (...)" 57

Alguns autores reconheceram a omissão constitucional, pugnando, contudo, pela reparação da ausência constatada, tendo em vista o fato de ter o constituinte previsto, até mesmo, a aferição concentrada diante da Carta Estadual. a qual não se repete na órbita federal. ${ }^{58}$ Impende trazer à baila o ensinamento de Regina Ferrari: ${ }^{5 y}$

O silêncio do legislador constituinte é questionável, mesmo reconhecendo que a maior parte desses conflitos acarretam, também, uma inconstitucionalidade no campo estadual, passiveis, segundo o art. $125, \S 2^{\circ}$, de serem analisados pelo

ss STRECK, Lenio Luiz. Jurisdição constitucional e hermenêutica: uma nova crítica do Direito. Porto Alegre: Livraria do Advogado, 2002. p. 568.

56 ROCHA. Fernando Luiz Ximenes. Controle de constitucionalidade de leis municipais. São Paulo: Atlas, 2001. p. 100.

57 VELOSO, Zeno. Controle jurisdicional de constitucionalidade. p. 354.

s8 FF.RRARI. Regina de Macedo Nery. A inconstitucionalidade da Lei .Municipal, cil.. p. 91. A autora chega a corroborar seu inconformismo com a opção do constituinte, prelecionando, em outra obra de sua lavra, que: "Parece ser omissão lastimável da parte do legislador constituinte não prever que o conflito se pode estabelecer entre a lei municipal e a Lei Maior da Federação brasileira. e ser argüido em processo de via de ação, quando previu por essa via até mesmo o controle da constitucionalidade das leis e atos municipais frente à Constituição Estadual" (Cf. FERRARI, Regina Maria Macedo Nery. Elementos de direito municipal. cit., p. 131). No particular, a aludida autora vê a existência de uma falha no sistema de controle de constitucionalidade brasileiro, constatando "(...) um hiato que só o tempo poderá completar" (C.f. FERRARI. Regina Maria Macedo Nery. Efeitos da declaração de incunstitucionalidade. p. 271).

$\because$ FERRARI. Regina de Macedo Nery. A inconstitucionalidade da Lei Municipal, cit. p. 99. 
Tribunal de Justiça dos Estados Membros. Porém, tais conflitos podem advir do confronto da lei e a Constituição Federal sem ofensa à Constituição Estadual e. nestes casos, deverão esperar que alguém venha alegar a incompatibilidade no curso de um processo comum, o que pode acarretar, ainda, a existência de decisões que operem, mas no sentido da constitucionalidade outras no da inconstitucionalidade do mesmo preceito normativo.

Importa demonstrar quais os argumentos esposados pela segunda corrente existente no tema. Neste sentido, propugna Vera Judith de Souza não poderem prosperar as opiniões daqueles que sustentam ser necessário aguardar a deflagração de lesão ou ameaça de lesão ao direito subjetivo de um municipe para que seja, então, feito o exame de constitucionalidade. ${ }^{60}$ A Autora pleiteia a permissão para que se realize o controle genérico de lei municipal pelo Supremo, salientando que “(...) a expressão lei municipal está inserida na abrangência do termo lei estadual, consagrado na previsão do art. 102, I, a da Constituição Federal". ${ }^{61}$

Argumenta, em síntese, que “(...) o Poder Legislativo municipal não podc ter uma autonomia legiferante mais ampla ou superior do que a dos Órgãos legislativos dos outros entes federados" 62 No particular, crítica frontal a este argumento partiu do professor Dalmo de Abreu Dallari, ${ }^{63}$ com a qual estamos de acordo.

De fato, a expressão lei municipal não pode ser tomada como parte da expressão lei estadual, até mesmo por conta do pressuposto teórico adotado neste trabalho. Ao considerar resguardadas pelo Constituinte as competências do Município, tomando-o como parte da Federação, resulta indevido submetê-lo a uma ingerência em sua autonomia, o que restaria aceito se a hipótese levantada fosse admitida. São distintas, portanto, as leis estaduais e municipais.

A questão foi, também, intensamente debatida no Supremo Tribunal Federal, tendo prevalecido o entendimento da impossibilidade de admissão do emprego de Ações de Inconstitucionalidade/Constitucionalidade visando à impugnação de leis

so SOUZA, Vera Judith de. O controle de constitucionalidade de lei municipal, em tese, pelo Supremo Tribunal Federal. In: MACHADO, Carlos Augusto Alcântara; MATOS, Fduardo Lima. Temas de direito constitucional.p. 341

II. ibid., p. 352.

62 Id. Ibid., p. 355.

6? "Fica evidente, portanto, que o Municipio brasileiro é pessoa jurídica de direito público interno, dotada dc autonomia politica e com uma esfera de competência própria e exclusiva, que decorre diretamente da Constituição Federal. Em conseqüência, quando o legislador brasileiro usa a expresssão estadual não pode ser considerada implicita a municipal, que não é integrante daquela" (Cf. DALLARI, Dalmo de Abreu. I ei municipal inconstitucional. In: Ação direta de controle da constitucionalidade de leis municipais $\mathrm{cm}$ lese, cit., p. 117-118). 
municipais em cotejo com a Carta Maior. Saliente-se. a respeito, o teor dos seguintes acórdãos:

Não compete ao Supremo Tribunal Federal processar e julgar, originariamente, ação direta de inconstitucionalidade contra lei ou ato normativo municipal, frente à Constituição Federal. Precedente: ADI 1.268 (AgRg)-MG. Despacho que negou seguimento a ADI, determinando seu arquivamento. Agravo regimental sustentando que a tese limitativa retira do Supremo Tribunal Federal a sua condição de guardião da Constituição Federal e, parcialmente, nega vigência an art. 102, da Constituição Federal, que perde a sua generalidade. Não cabe enquadrar na compreensão de lei ou ato normativo estadual, ut art. 102, I, da Constituição, as leis municipais. Precedente: ADI 409-3/600 (ADI 1.886 - AgR, Rel. Min. Néri da Silveira. DJ 17/12/1999).

Reclamação. Ação Direta de Inconstitucionalidade de Lei Municipal em face da Constituição Federal. Competência. Ajuizamento perante Tribunal de Justiça Estadual. Lei Municipal. Inconstitucionalidade por ofensa a Constituição Federal. Argüição "in abstrato": por meio de ação direta. perante Tribunal de Justiça. O nosso sistema constitucional não admite o controle concentrado de constitucionalidade de lei ou ato normativo municipal em face da Constituição Federal; nem mesmo perante o Supremo Tribunal Federal que tem, como competência precípua, a sua guarda, art. 102. O único controle de constitucionalidade de lei e de ato normativo municipal em face da Constituição Federal que se admite é o difuso, exercido "incidenter tantum", por todos os órgãos do Poder Judiciário, quando do julgamento de cada caso concreto (Rcl. 337 Rel. Min. Paulo Brossard, DJ 19/12/1994).

(...) 10. Com efeito, a compctência do Supremo Tribunal Federal, em Ação Direta de Inconstitucionalidade, é a de declarar a inconstitucionalidade de lei ou ato normativo federal ou estadual, como está expresso no art. 102, 1, "a", da Constituição Federal, quando afrontada esta última. E não de lei de natureza municipal. 11. Em se tratando de lei municipal, o controle de constitucionalidade se faz pelo sistema difuso - e não concentrado - ou seja, apenas no julgamento de casos concretos, com eficácia "inter partes" e não "erga omnes". quando confrontado o ato normativo local com a Constituição Federal (ADI 209. Rel. Min. Sydney Sanches, DJ 11/09/98).

Diante do exposto, pode-se asseverar ser impossivel o exame. na via abstrata, de leis municipais perante o Supremo. A doutrina do silêncio eloqüente foi 
endossada pelo STF e pela maioria da doutrina brasileira, ${ }^{64}$ conduzindo à aceitação da impossibilidade de se perquirir, via ação de inconstitucionalidade, a análise da lei municipal perante a Carta Maior.

\subsubsection{A Argüição de Descumprimento de Preceito Fundamental}

Atualmente, o problema ganhou novos contornos em razão do surgimento da Argüição de Descumprimento de Preceito Fundamental (ADPF), ${ }^{65}$ a qual permite a fiscalização de constitucionalidade de leis municipais que firam preceitos fundamentais. Neste sentido, preleciona Patrícia Flores ${ }^{66}$ que:

(...) registra-se, em conclusão, que a argüição de
descumprimento de preceito fundamental possibilitará o
controle concentrado de constitucionalidade de lei ou ato
normativo municipal em face da Constituição Federal
perante o Supremo Tribunal Federal. Antes do advento da
Lei $9.882 / 99$, ${ }^{67}$ somente pela via difusa era possível, em
relação aos atos locais, o controle de sua validade
constitucional, tendo como parâmetro o Texto Maior.

Não houve, na verdade, resolução definitiva da problemática, tendo em vista o fato de que as leis municipais passíveis de verificação são apenas aquelas que atingem parte específica da Constituição - compreendida, no caso, como sendo preceito fundamental -, não se destinando à sua tutela integral. Ademais, impende ressaltar ser a ADPF instituto ainda envolto em uma aura de imprecisão jurídica elevada, ${ }^{68}$ o que não-

G. "Denota-se, pois, que, a exemplo da ordem constitucional anterior, não há, no direito brasileiro, ação direta de inconstitucionalidade e lei ou ato normativo municipal tendo como parâmetro a Constituição Federal. Equivale dizer, a invalidade de um ato local, em face da Carta Magna, só pode ser decretada via controle difuso. exercitável incidenter tantum" (Cf. FLORES, Patricia Teixeira de Rezende. Aspectos processuais da Ação Direta de Inconstitucionalidade de Lei Municipal. p. 113).

63 A ADPF surgiu, ressalte-sc, no interior de regra de baixíssima densidade normativa, como salienta o professor Elival da Silva Ramos (Cf. RAMOS, Elival da Silva. Argüição de Descumprimento de Preceito Fundamental: Delineamento do Instituto. In: Argüição de descumprimento do preceito fundamental: análises à luz da Lei n. 9.882/99, p. 109).

66 FLORES, Patrícia Teixeira de Rezende. Aspectos processuais da Ação Direta de Inconstitucionalidade de' Lei Municipal. São Paulo: Revista dos Tribunais, 2002. p. 362.

6) A autora se refere à legislação de 1999 por conta de ter prevalecido, no seio do STF. a interpretação de que o uso da ADPF somente restaria admitido quando fosse expedida a regulamentação necessária. Neste sentido: "Vale dizer, enquanto não houver lui estabelecendo a forma pela qual será apreciada a argüição de descumprimento de preceito fundamental, decorrente da Constituição, o STF não pode apreciá-la" (STF. Ag. Reg. Pet. 1140-7/TO Rel. Min. Sydney Sanches. Tribunal Pleno. Decisão: 02/05/96. DJ 1 de 31.05.96, p. 18.803).

68 Neste sentido, cf. SARLET, Ingo Wolfgang. Argüição de Descumprimento de Preceito Fundamental: alguns aspectos controversos. In: Revista Diálogo Juridico. Salvador: CAJ - Centro de Atualização Juridica. V. I. n. 3, junho, 2001. Disponível em: <http://www.direitopublico.com.br $>$. Acesso em: 06 maio 2005. p. 1-2. 
permite efetuar grandes expectativas acerca da inovação inserida em nosso ordenamento. ${ }^{69}$

\subsection{O problema da norma repetida}

Outro tópico particularmente relevante se refere à hipótese da lei municipal ferir comando normativo previsto na Constituição Estadual que repete, em sua letra, alguma prescrição constante na Constituição Federal. Trata-se do problema da norma repetida, sendo relevante destacar que ela pode assumir duas manifestações: configurar-se como norma estadual que repete preceito federal de observância obrigatória no âmbito estadual, ou, ao contrário, tratar-se de norma estadual que apenas imita a disciplina federal existente em alguma matéria específica.

Discutiu-se, no seio do Supremo, se a norma estadual que repete norma federal de obrigatória observância seria norma jurídica autônoma. A negativa desta conclusão conduziria à aceitação de que se uma determinada ação de inconstitucionalidade que tivesse por objeto lei municipal ofensora da norma estadual repetida fosse examinada pelo Tribunal de Justiça local estar-se-ia consagrada subtração do comando constitucional que determina caber a guarda da Constituição ao STF.

A princípio, firmou-se o entendimento de que as aludidas normas não eram normas autônomas, o que determinava, portanto, como local competente para processamento e julgamento de tais ações única e exclusivamente o STF, questão enfrentada na Reclamação n. 370. A respeito, ensina Moreira Alves que:

Sustentou-se, então, a partir da distinção entre normas constitucionais estaduais que imitam a disciplina constitucional federal (e cuja eficácia resulta da autonomia dos Estados) e normas constitucionais estaduais que reproduzem normas constitucionais federais obrigatórias a todos os niveis da federação (e cuja eficácia existiria independentemente dessa reprodução), que as normas dessa segunda espécie "em termos estritamente jurídicos é ociosa", o que implica dizer que "só aparentemente são normas estaduais", mas verdadeiramente, por não poderem inovar na ordem juridica, sequer são normas jurídicas. (...) Tal conclusão importa a afirmação de que ações diretas de inconstitucionalidade em face desses preceitos contidos nas

69 Importa destacar, por oportuno, ter sido prolatado o primeiro julgamento de mérito do STF em sede de ADPF, decisão que pode vir a contribuir para aperfeiçoar a compreensão do instituto ( $\mathrm{Cf}$. O rosto da ação - Supremo julga a primcira ADPF e define contorno da ação. Disponível em: <http://conjur.estadao.com.br/static/text40076,1>. Acesso em: $11 \mathrm{dez}$. 2005). Para uma melhor compreensão da ADPF, consultar: TAVARES, André Ramos. Tratado da argüição de preceiro fundamental. 
Constituições Estaduais são, na verdade, ações diretas de inconstitucionalidade em face da Constituição Federal, e, como tais, devem ser julgadas ${ }^{i 0}$ (grifo nosso).

Posteriormente, contudo, operou-se mudança substancial nesse entendimento, passando a Corte Suprema a admitir o conhecimento de processos que envolvessem norma repetida pelo próprio Tribunal de Justiça local, e consagrando-se, desta forma, a aceitução da normatividade autônoma da norma repetida. Acórdão exemplar neste sentido foi o prolatado na Reclamação Constitucional n. 383, relatada pelo ministro Moreira Alves, preceituando que:

Reclamação com fundamento na preservação da competência do Supremo Tribunal Federal. Ação direta de inconstitucionalidade proposta perante Tribunal de Justiça na qual se impugna lei municipal sob a alegação de ofensa a dispositivos constitucionais estaduais que reproduzem dispositivos constitucionais federais de reprodução obrigatória pelos Estados. Eficácia juridica desses dispositivos constitucionais estaduais. Jurisdição constitucional dos Estados-Membros. Admissão da propositura da ação direta de inconstitucionalidade perante o Tribunal de Justiça local, com possibilidade de recurso extraordinário se a interpretação da norma constitucional estadual, que reproduz a norma constitucional federal de observância obrigatória pelos Estados, contrariar o sentido e o alcance desta. (Rcl 383, Rel. Min. Moreira Alves, DJ $21 / 05 / 93)$. $^{7 \cdot}$

i* ALVES, José Carlos Moreira. A jurisdição constitucional estadual e as normas constitucionais federais reproduzidas nas Constituiçǒes dos Estados-Membros. In: MARTINS, Ives Gandra da Silva (Coord.) As vertentes do direito constitucional contemporâneo. Rio de Janeiro: América Juridica, 2002. p. 21 .

No mesmo sentido, cf. Rel. 596-AgR, Rel. Min. Néri da Silveira, DJ 14/11/96; Rel. 2076, Rel. Min. Ilmar Galvão, DJ 08.11.2002. O próprio Moreira Alves defende, de forma lapidar, a necessidade de mudança do posicionamento primeiramente por ele narrado: "Essas observações todas servem para mostrar, pela inadmissibilidade das conseqüèncias da tese que se examina, que não é exato pretender-se que as normas constitucionais estaduais que reproduzem as normas centrais da Constituição Federal (e o mesmo ocorre com as leis federais ou até estaduais que fazem a mesma reprodução) sejam inócuas e, por isso, não possam ser cunsideradas normas jurídicas. Essas normas são normas juridicas, e têm eficácia no seu âmbito de atuação, até para permitir a utilização dos meios processuais de tutela dessé âmbito (como o recurso especial. no tocante ao ant. $6^{\circ}$ da Lei de Introdução ao Código Civil, e as ações diretas de inconstitucionalidade em face da Constituição Estadual)" (ALVES, José Carlos Moreira. op. cit. p. 25). 
Passou-se a reconhecer, a partir deste momento, ${ }^{72}$ que a norma constitucional estadual que reproduzia dispositivo federal possuia eficácia juridica, o que conduz à permissão da instituição de seu controle de constitucionalidade. Saliente-se. no caso, o entendimento de Sacha Calmon Navarro Coelho: ${ }^{3}$

Pois bem, se a Constituição dos Fstados, leis estaduais e municipais, bem como atos normativos estaduais e municipais malferirem a Constituição Federal, a competência para resolver a questão é do Supremo Tribunal Federal. Do mesmo modo, por derivação lógica. se a Constituição Fistadual repetir norma já constante da Constituição Federal a transgressão da mesma implica em dupla inconstitucionalidade, devendo dirimir o conflito o Supremo Tribunal Federal. Somente quando a Constituição Estadual é atingida em sua normatividade autônoma, a competência para apreciar a inconstitucionalidade é do Tribunal de Justiça do Estado-Membro.

Ademais. importa prelecionar configurar-se solução curiosa, no particular, a permissão para controle de constitucionalidade de leis municipais diante de normas de reprodução, por conta de ser a única possibilidade atualmente admitida para que qualquer norma municipal venha a ser examinada, no campo do controle principal, pelo Supremo. ${ }^{74}$ No particular, leciona Zeno Veloso: ${ }^{-5}$

$\because$ (omo exemplo da nova opção do Supremo, cf. o seguinte acórdão: "Competência. Ação direta de inconstitucionalidade. Lei municipal contestada em face da Carta do Estado, no que repete preceito da Constituição Federal. $\mathrm{O} \$ 2^{\circ}$ do art. 125 do Diploma Maior não contempla exceção. A competência para julgar a ação direta de inconstitucionalidade é definida pela causa de pedir lançada na inicial. Em relação ao conflito da norma atacada com a Lei Máxima do listado, impõe-se concluir pela competência do Tribunal de Justiça, pouco importando que o preceito questionado mostre-se como mera repetição de dispositivo, de adoção obrigatória, inserto na Carta da República. Precedentes: Reclamação n $383 / \mathrm{SP}$ e Agravo Regimental na Reclamação $n^{\circ} 425$, relatados pelos ministros Moreira Alves e Néri da Silveira, com acórdãos publicados nos Diários de Justiça de 21 de maio de 1993 e 22 de outubro de 1993 , respectivamente" (RE 199.293, Rel. Min. Marco Aurélio, DJ 06/08/04). Neste mesmo sentido, v.: "É competente o Tribunal de Justiça (e não o Supremo Tribunal) para processar e julgar ação direta contra lei estadual contrastada com a norına da Constituição local, mesmo quando venha esta a consubstanciar mera reprodução de regra da Carta Federal, cabendo, em tese, recurso extraordinário de decisão que vier a ser proferida sobre a questão" (ADI 1529-QO, Rel. Min. Octávio Gallotti. DJ 28/02/97).

73 COÊLHO, Sacha Calmon Navarro. O controle da constitucionalidade das leis e du poder de triburar na Constituição de 1988. 3. cd. Belo Horizonte: Del Rey, 1999. p. 200. Scgundo ele; "Esta é a melhor solução para resolver a chamada inconstitucionalidade reflexa, ou seja, a argüição direta de incunstitucionalidade por ferir a lei ou ato normativo dispositivo da Lei Maior, repetido numa Constituição Estadual, resguardando-se a uniformidade na interpretação da Constituição Federal". Malgrado seja esta a opinião do autor, ele reconhece a posição do Supremo a respeito: "O STF, contudo, instituiu uma solução sui generis. Passou a admitir que os Tribunais de Justiça conhecessem a chamada inconstitucionalidade reflexa ou de norma federal repetida na Constituição Estadual. No entanto não abdicou de sua competência. Das decisões dos Tribunais Fstaduais cabe recurso para o STF" (op. cit. p. 201).

7. Com exceção da ADPF, na qual, como ressaltado. apenas leis municipais que ferem preceitos fundamentais são suscetiveis de controle.

75 VELOSO, Zeno. Controle jurisdicional de constitucionalidade: atualizado conforme as Leis 9.868, du 10.11.1999 e 9.882, de 03.12.1999. 3. ed. 2. tir. rev. atual. e ampl. Belo Horizonte: Del Rey. 2003. p. 357. 
Embora não seja admissivel, nem pelo próprio Supremo Tribunal, nem pelos Tribunais de Justiça, o controle in ahstrato da lei municipal em face da Constituição Federal, ou seja, ainda que não seja cabivel estabelecer um juizo de parametricidade direto e imediato entre a legislação edilícia e as normas da Carta Magna, diante daquela nova orientação do STF, somos levados a concluir que esta confrontação entre lei municipal e norma constitucional federal será possível fazer pelo Tribunal de Justiça, quando o preceito da Carta Estadual. diante da qual é contestada a lei municipal, representar norma de reprodução, isto é, significar simples cópia ou repetição de regra constitucional federal. Caberá, todavia, recurso para o Pretório Excelso, e, para garantir e resguardar a competência deste, deveria ser instituido o recurso necessário, para o Supremo Tribunal, das decisões que tomassem os Tribunais de Justiça, quando analisassem o confronto duplo da lei municipal - com a Constituição Estadual e com a Carta Magna. Esta sugestão foi feita pelo eminente ministro Carlos Velloso.

Portanto, em caso de norma federal reproduzida em Constituição Estadual, resulta possível o emprego do controle de constitucionalidade abstrato de lei municipal que fira o teor presente em ambos ${ }^{76}$ os diplomas normativos, podendo tanto o TJ quanto o STF ter contato com a controvérsia. ${ }^{77}$ Caso seja eleita a primeira via, ressalte-se,

76 No caso de violação de dispositivo original da Constituição Estadual a decisão do TJ é detinitiva (FERRARI. Regina Maria Macedo Nery. Controle de constitucionalidade de leis municipais, cit., p. 124).

$n$ "Em sintese, se a lei ou o ato normativo municipal estiver em confronto com a Constituição Federal, não há como se aplicar. em nivel estadual, o sistema de controle concentrado de constitucionalidade. Todavia. se us disposições constitucionais federais estiverem reproduzidas na Carta Estadual, a análise da constitucionalidade é viável (...)" (DLLLA GIUSTINA, Vasco. Leis municipais e süll controle constitucional pelo Tribunal de Jusıţ̧a. Porto Alegre: Livrarria do Advogado, 2001 . p. 86). 
permanecerá a possibilidade de recurso ao Supremo, ${ }^{78}$ o qual não abandonou sua competência de guardião último da Lei Maior. ${ }^{79}$

6. Uma proposta de reformulação

Diante da controvérsia examinada, cumpre destacar nosso entendimento particular acerca do tema. Defende-se, no bojo deste trabalho, a alteração da Constituição Federal com o intuito de proceder à inserção da lei municipal como objeto de aferição de constitucionalidade no âmbito das Ações de Inconstitucionalidade/Constitucionalidade existentes no ordenamento nacional.

De fato. configurou-se silêncio eloqüente a falta de previsão da lei municipal no texto constitucional, caracterizando-se vontade expressa restritiva da inclusão da norma municipal. Crer, portanto, na possibilidade de extensão da competência prevista constitucionalmente para abarcar os diplomas municipais se afigura posicionamento inadmissível, exigindo a matéria processo formal de mudança no conteúdo normativo da Lei Magna.

Sugere-se, então, como forma de tornar mais completo o modelo brasileiro de controle de constitucionalidade, a inclusão da lei municipal como objeto de fiscalização abstrata de constitucionalidade, reforma que deve ser feita mediante o uso de emenda constitucional.

A princípio, à evidência, nem toda questão envolvendo lei municipal precisaria necessariamente ter o mérito adentrado no Supremo. Torna-se admissível a construção de alguma espécie de restrição ${ }^{80}$ no manuseio da Ação de Inconstitucionalidade que albergue questionamento sobre lei municipal, para que se

\footnotetext{
"Sobrestamento da ação dircta no àmbito estadual até o julgamento do mérito da que tramita perante o STF (...) Verificada a reprodução obrigatória pela Carta Estadual (art. 76, incisos I, Il, IV, V e VI) das disposições constantes dos incisos I, II, IV, V e VI do art. 71 da Constituição Féderal, é du STF a competência para julgar a ação (...) Se a ADI é proposta inicialmente perante o Tribunal de Justiça local c a violação suscitada diz respeito a preceitos da (arta da República, de reprodução obrigatória pelos Estados-membros, deve o Supremo Tribunal Federal, nesta parte, julgar a ação, suspendendu-se a de lá; se além das disposições constitucionais federais há outros fundamentos envolvendo dispositivos da Constituição do Estado, a ação ali cm curso deverá ser sobrestada até que esta Corte julgue em definitivo o mérito da controvérsia" (ADI 2.361-MC, Rel. Min. Mauricio Corrêa, DJ 01/08/03). Neste mesmo sentido, cl.: "Coexistência de jurisdiçōes constitucionais estaduais e federal. Propositura simultânea de ADI contra lei estadual perante o Supremo Tribunal Federal e o Tribunal de Justiça. Suspensão do processo no àmbito da justiça estadual, até a deliberação definitiva desta Corte. Precedentes. Declaração de inconstitucionalidade, por esta Corte, de art.s da lei estadual. Argüição pertinente à mesına norma requerida perante a Corte estadual. Perda de objeto" (Pet 2.701-AgR, Rel. p/ o ac. Min. Gilmar Mendes. DJ 19/03/04).

79 Cf. ISERN, Luiz Francisco. op. cit. p. 63: "Cumpre ressaltar que o Supremo Tribunal Federal passou a admitir que os Tribunais de Justiça conhecessem a chamada inconstitucionalidade reflexa ou de norma federal repetida na Constituição estadual. No entanto não abdicou de sua competència. Das decisões dos Tribunais Estaduais cabe recurso para o Supremo Tribunal Federal"
} 
permita que somente temas de grande impacto e de relevância corroborada possam ser analisados pelo Pretório Excelso. ${ }^{81}$

Malgrado se possa questionar, por outro lado, o aumento do númcro de feitos que viriam a ser submetidos à apreciação do STF, torna-se oportuno destacar uma indagação: estaria a capacidade operacional do Supremo sendo ocupada, na atualidade, com as demandas que, verdadeiramente, deveriam ser postas sob sua apreciação?

A resposta negativa se impõe. Sabe-se ser o Supremo, hodiernamente, instância recursal que funciona para exame de uma enorme multiplicidade de assuntos, incluindo-se, no particular, temas completamente distanciados da jurisdição constitucional. Vale ressaltar até que ponto se pode, pois, contar com a funcionalidade do atual modelo do STF, questão que, inclusive, sugere a criação de uma Corte exclusivamente destinada ao trato da matéria constitucional. ${ }^{82}$

A singela inserção da lei municipal como objeto de controle desacompanhada da mudança no perfil institucional do Supremo - não servirá, de forma alguma, para a melhoria de nossa sistemática de jurisdição constitucional. Contudo, não se pode deixar de reconhecer a existência de uma falha em nosso modelo de controle de constitucionalidade, permitindo-se que paire a lei municipal sem possibilidade autônoma de análise pelo guardião da Constituição. ${ }^{83}$

Importa, pois, empreender alteração no sistema, para que se alcance maior eficácia na atividade de proteção da Lei Maior, que se configura como objetivo último de todo o controle de constitucionalidade.

Ante todo o exposto, e a título de conclusão, pode-se aferir que, por meio do controle de constitucionalidade ocorre verdadeira preservação da integridade da Constituição, colaborando-se para o recrudescimento de seu teor normativo e para a garantia de proteção à sua força vital. O objetivo central do trabalho se volta, destarte, para o aperfeiçoamento do nosso sistema de controle, com o que se aperfeiçoa também a proteção à Lei Maior.

A Constituição da cada povo representa, na verdade, a imagem do seu desejo de futuro, refletida no espelho contínuo da história: embora. às vezes. pareçam

so Algo similar já foi feito pelo Supremo quando, por exemplo, desenvolveu a idéia de pertinéncia temática como critério que viesse a limitar a impetração de ADIN pelos legitimados do art. 103 da CF/88.

yi Importa destacar que outras Cortes Supremas do mundo trabalham com um pequeno número de ações por conta. dentre outros fatores, do rigor em sua admissibilidade, como faz, por exemplo, o Tribunal Constitucional Alemão (C'f. MORAES, Alexandre de. Jurisdição constitucional e tribunais constitucionais, cit., p. 166).

82 Concordamos, portanto. com o posicionamento do professor Alexandre de Moraes quando sugere a transformação do STF em Corte Constitucional. A respeito, cf.: MORAES, Alexandre de. op. cit. p. $287 \mathrm{e}$ 324.

* Salvo, como visto, nos casos de norma repetida e de lei municipal que fira preceito fundamental. 
estar distantes as transformações efetivas da realidade, resulta inteiramente vedado olvidar o sonho com o alcance do rol de desejos nela insculpidos. A fiscalização de constitucionalidade configura-se como a moldura que guarnece e prestigia o conteúdo da vontade suprema da Nação. Cabe ao jurista, por sua vez, representar o papel de artista habilidoso, laborando com a finalidade de fazer com que a supremacia constitucional seja definitivamente respeitada.

Conclusões

1. Nascido em Roma, o Município ostenta feições distintas na atualidade. sendo componente, no Brasil, de nosso sistema federativo, o qual se compõe de tripla ordem funcional.

2. No campo do controle incidental de constitucionalidade de leis municipais há permissão para a aferição ampla - ou seja, por qualquer órgão do Poder Judiciário - da compatibilidade de tais diplomas com a Carta Maior, seja utilizando como parâmetro a Constituição Estadual ou empregando, para tanto, a Constituição da República. Pode ocorrer a resolução do conflito exclusivamente na seara do EstadoMembro (mediante o Tribunal de Justiça), mas também se permite, em caso de violação de norma presente simultaneamente nas duas Cartas, que o STF tome parte da controvérsia mediante o emprego de recurso extraordinário.

3. O controle principal de constitucionalidade da lei municipal diante da Carta Estadual é permitido, tendo em vista a existência de artigo específico a respeito do tema na Constituição de 1988. Da mesma forma, pode o Supremo vir a conhecer a controvérsia em caso de violação de norma obrigatoriamente reproduzida.

4. A ausência de contemplação expressa da lei municipal como objeto do controle abstrato tendo como parâmetro a Constituição Federal configura-se como silêncio eloqüente (beredtes schweigen), evidenciando expressa vontade de restringir os diplomas normativos passíveis dessa modalidade de fiscalização constitucional.

5. Sugere-se a inclusão, mediante emenda constitucional, da lei municipal como objeto das Ações de Constitucionalidade/Inconstitucionalidade existentes em nivel federal, conduta que contribui para tornar mais completo o sistema nacional de controle de constitucionalidade. Repudia-se, no particular, a argumentação que atenta apenas para a preservação da capacidade operacional do Pretório Excelso, a qual desconsidera a necessidade de prestigiá-lo com o fortalecimento de sua posição institucional.

6. O controle de constitucionalidade se revela, portanto. como mecanismo vital para o fortalecimento do respeito à força normativa e integridade da Carta Magna. 
devendo ser respeitado em todas as suas manifestações, nele exercendo o jurista papel destacadamente valioso.

São Paulo, setembro de 2006.

\section{Referências}

ALMEIDA, Fernanda Dias Menezes de. Competências na Constituiçâo de 1988. 3. ed. São Paulo: Atlas, 2005.

ALVES, José Carlos Moreira. A jurisdição constitucional estadual e as normas constitucionais federais reproduzidas nas Constituições dos Estados-Membros. In: MARTINS, Ives Gandra da Silva (Coord.) As vertentes do direito constitucional contemporâneo. Rio de Janeiro: América Jurídica, 2002.

ARISTÓTELES. Politica. São Paulo: Martin Claret, 2004.

BAHIA, Saulo José Casali. A Federação brasileira. Revista Juridica dos Formandos em Direito da UFBA. Ano III. Vol. IV. Grupo de Formatura de 1998.2. Edição em homenagem ao Professor Orlando Gomes. Temas Jurídicos à luz dos dez anos da Constituição. Salvador: Envelope \& Cia., 1998.

BARROSO, Luís Roberto. O controle de constitucionalidade no Direito brasileiro: exposição sistemática da doutrina e análise crítica da jurisprudència. São Paulo: Saraiva, 1994.

BASTOS. Celso Ribeiro. Comentários à Constituição do Brasil: promulgada em 5 de outubro de 1988. volume 4 - arts. 92 a 126. São Paulo: Saraiva, 1997.

Curso de direito constifucional. 19. ed. atual. São Paulo: Saraiva. 1998.

BITTENCOURT, Carlos Alburto Lúcio. O Controle Jurisdicional da Constitucionalidade das Leis. 2 ed. Brasília: Ministério da Justiça, 1997.

BONAVIDES, Paulo. A constituição aberta. Belo Horizonte: Del Rey, 1993.

História constitucionul do Brasil. 5. ed. Brasilia: OAB Editora. 2004.

CASTRO, José Nilo de. Direito inunicipal positivo. Belo Horizonte: Del Rey, 1991.

CLE்VE, Clèmerson Merlin. A fiscalizaçâo abstrata de constitucionalidade no direito hrasileiro. São Paulo: Revista dos Tribunais, 1995.

COÊLHO, Sacha Calmon Navarro. O controle da constitucionalidade das leis e do poder de tributar na Constituição de 1988. 3. ed. Belo Horizonte: Del Rey, 1999. 
CRETELLA JÚNIOR, José. Elementos de direito constitucional. 2 ed. rev. São Paulo: Revista dos Tribunais, 1998.

DANTAS, Ivo. O valor da constituiçāo: do controle da constitucionalidade como garantia da supralegalidade constitucional. 2 ed. rev. aum. Rio de Janeiro: Renovar, 200 l.

DELLA GIUSTINA. Vasco. Leis municipais e seu controle constitucional pelo Tribunal de Justiça. Porto Alegre: Livraria do Advogado, $200 \mathrm{I}$.

FERRARI, Regina Maria Macedo Nery. A Inconstitucionalidade da Lei Municipal. Curitiba: Juruá, 1991.

Controle de constitucionalidade de leis municipais. 2. ed. rev. e ampl. Do livro $A$ inconstitucionalidade da lei municipal. São Paulo: Revista dos Tribunais, 1994.

Efeitos da declaração de inconstitucionalidade. 4. ed. rev.. atual. e ampl. São Paulo: Revista dos Tribunais, 1999.

. Elementos de direito municipul. São Paulo: Editora Revista dos Tribunais, 1993.

FERRAZ, Anna Cândida da Cunha. Poder constituinte dos estados-membros. São Paulo: Revista dos Tribunais, 1979.

FERRAZ JR., Tércio Sampaio. Teoriu da norma juridica: ensaio de pragmática da comunicação normativa. 3 ed. Rio de Janeiro: Forense, 1999.

FERREIRA, Pinto. (urso de direito constitucional. 8. ed. ampl. c atual. de acordo com as Emendas Constitucionais e a Revisão Constitucional. São Paulo: Saraiva, 1996.

FERREIRA FILHO, Manoel Gonçalves. Comentários à Constituição brasileira de 1988. volume I - arts. $1^{\circ}$ a 103 . São Paulo: Saraiva. 2000.

Curso de direito constitucional. 27. ed. atual. São Paulo: Saraiva, 2001.

FLORES, Patricia Teixeira de Rezende. Aspectos processuais da Ação Direta de Inconstitucionalidade de Lei Municipal. São Paulo: Revista dos Tribunais, 2002.

FRANCO, A fonso Arinos de Mulo. Direito constitucional: teoria da Constituição; as Constituições do Brasil. Rio de Janeiro: Forense, 1976.

FRIEDE, Reis. ('urso Analitico de Direito Constitucional e de Teoria (ieral do Estado. Rio de Janeiro: Forense, 1999.

HORTA, Raul Machado. Direito Constitucional. 4. ed. rev. e atual. Belo Horizonte: Del Rey, 2003. 
ISERN, Luiz Francisco. Controle de constitucionalidade por meio do veto municipul. São Paulo: Método, 2002.

KELSEN, Hans. Teoriu geral do direito e do estado. Tradução Luís Carlos Borges. 3. ed. São Paulo: Martins Fontes, 1998.

LARENL, Karl. Metodologia de la ciencia del derecho. Traducción de Enrique Gimbernat Ordeig. Barcelona: Ariel, 1966.

LOEWENSTEIN, Karl. Teoria de la constitucion. Traducción y estudio sobre la obra por Alfredo Gallego Anabitarte. Barcelona: Ariel, 1964.

MEIRELLES, Hely Lopes. Direito municipal brasileiro. 7. ed. atual. Por Izabel Camargo Lopes Monteiro e Yara Darcy Police Monteiro. São Paulo: Malheiros, 1994.

MENDES, Gilmar Ferreira. Controle de constitucionalidade: aspectos jurídicos e políticos. São Paulo: Saraiva, 1990.

MORAES, Alexandre de. Direito constitucional. 12. ed. São Paulo: Atlas, 2002.

. Jurisdição constitucional e tribunais constitucionais: garantia suprema da constituição. 2. ed. São Paulo: Atlas, 2003.

RAMOS, Elival da Silva. A inconstitucionalidade das leis: vício e sanção. São Paulo: Saraiva, 1994.

Argüição de Descumprimento de Preceito Fundamental: Delineamento do Instituto. In: TAVARES, André Ramos; ROTHENBURG, Walter Claudius. Argüição de descumprimento de preceito fundamental: análises à luz da Lei n. 9.882/99. São Paulo: Atlas, 2001.

ROCHA, Fernando Luiz Ximenes. Controle de constitucionalidade de leis municipais. São Paulo: Atlas, 2001.

SARLET, Ingo Wolfgang. Argüição de Descumprimento de Preceito Fundamental: alguns aspectos controversos. In: Revista Diálogo Jurídico. Salvador: CAJ - Centro de Atualização Jurídica. V. I. n. 3, junho, 2001. Disponivel em: <http://www.direitopublico.com.br>. Acesso em: 06 maio 2005.

SÃO PAULO (Estado). Procuradoria Gcral. Ação direta de controle da constitucionalidade de leis municipais em tese. São Paulo: Centro de Estudos da Procuradoria Geral do Estado, 1979.

SILVA, José A fonso da. Curso de Direito Constitucional Positivo. 20. ed. São Paulo: Malheiros, 2002.

O municipio na Constituição de 1988. São Paulo: Revista dos Tribunais, 1989. 
SOUZA, Vera Judith de. O controle de constitucionalidade de lei municipal, em tese, pelo Supremo Tribunal Federal. In: MACHADO, Carlos Augusto Alcântara; MATOS, Fduardo Lima. Temas de direito constitucional. Aracaju: J. Andrade, 2002.

STRECK. Lenio Luiz. Jurisdição constitucional e hermenêutica: uma nova crítica do Direito. Porto Alegre: Livraria do Advogado, 2002.

TAVARES, André Ramos. Tratado da argiiição de preceito fundamental. São Paulo: Saraiva, 2001.

TEMER, Michel. Elementos de direito constitucional. 12. ed. São Paulo: Malheiros. 1996.

THEODORO JÚNIOR, Humberto. Curso de Direito Processual (ivil. 32. ed. Rio de Janeiro: Forense, 2000. v. 1.

VELOSO, Zeno. Controle jurisdicional de constitucionalidade: atualizado conforme as I eis 9.868. de 10.11.1999 e 9.882, de 03.12.1999. 3. ed. 2. tir. rev. atual. e ampl. Belo Horizonte: Del Rey, 2003. 